\title{
CITIZENS' PARTICIPATION IN ELECTORAL GOVERNANCE: A REDISTRICTING PROCESS
}

\section{Nikolai V. Grishin (a)}

(a) Saint Petersburg State University. St. Petersburg, Russia. E-mail: nvgrishin[at]mail.ru ORCID. 0000-0002-0850-7581

\section{Abstract}

Citizens' participation in electoral governance can be considered as a means for insuring electoral integrity. Some cases and problems of this participation are discussed in contemporary literature. Less attention has been paid to institutional forms of citizens' participation in electoral redistricting. The paper presents a systematic picture to fill this gap, it also reveals the prospects of citizens' participation in this area of electoral governance. Methodological framework for the study is contemporary theory of citizens' participation and the S. Arnstein 's "ladder" of citizens' participation. Making cross-case generalisations, the paper addresses the empirical material from Australia, New Zealand, Canada, India, Great Britain, the USA and Russia. It is conceivable that the adequate time frame for citizens' participation and transparency are the most significant conditions for citizens`engagement.

\section{Key words}

citizens' participation; ladder of citizen participation; delimitation of constituencies; redistricting; electoral management; electoral governance; electoral authorities; electoral integrity; constituencies; elections; electoral systems

This work is licensed under a Creative Commons «Attribution» 4.0 International License 


\section{УЧАСТИЕ ГРАЖДАН В УПРАВЛЕНИИ ВЫБОРАМИ: ПРОЦЕСС ДЕЛИМИТАЦИИ ИЗБИРАТЕЛЬНЫХ ОКРУГОВ}

\section{Гришин Николай Владимирович (a)}

(a) Санкт-Петербургский государственный университет. Санкт-Петербург, Россия. E-mail: nvgrishin[at]mail.ru ORCID 0000-0002-0850-7581

\section{Аннотация}

Участие граждан в управлении выборами можно рассматривать как средство обеспечения честности выборов. Некоторые случаи и проблемы этого участия обсуждаются в современной литературе. Меньшее внимание уделяется институциональным формам участия граждан в процессе делимитации избирательных округов. Чтобы восполнить этот пробел, в данной статье представлена систематическая картина и раскрываются перспективы гражданского участия в этой сфере управления выборами. Методологической основой исследования является современная теория участия граждан и «лестница гражданского участия» С. Арнштейн. На основе обобщения данных, в статье рассматривается эмпирический материал из Австралии, Новой Зеландии, Канады, Индии, Великобритании, США и России. Допустимо, что адекватные временные рамки для участия граждан и прозрачность являются наиболее важными условиями повышения степени вовлечения граждан.

\section{Ключевые слова}

участие граждан; лестница гражданского участия; делимитация избирательных округов; управление выборами; электоральный менеджмент; электоральная политика; избирательные органы; избирательные округа; выборы; избирательные системы

Это произведение доступно по лицензии Creative Commons «Attribution» («Атрибуция») 4.0 Всемирная 


\section{INTRODUCTION}

The process of electoral redistricting is of great importance in the elections of legislative and representative authorities. If the electoral system with single member district is used then manner of redistricting can be crucial for candidates and for the composition of a parliament. The process of electoral districts redistricting is one of the most acute and conflictogenic in the process of electoral management (Morozova, 2013, p. 109). The choice of a particular approach for redistricting is often determined by partisan motives and causes significant political consequences, reducing or increasing the chances for certain political parties (Winburn \& Wagner, 2010, p. 380; Hunt, 2018).

According to the web portal ACE Electoral Knowledge Network, in $69 \%$ of countries in the world there is a practice of systematic redistricting (Best, 2018). As a rule, if the delimitation of electoral districts does not take place in the country, it is a consequence of the use of a proportional representation electoral system, in which single member districts are absent usually.

As one of the areas of electoral governance, the process of delimitation of electoral districts includes a set of institutions, among which there are institutions of citizens' participation. Citizens' participation in redistricting can democratize the decision-making process and move it beyond the political elite (Nagle, 2019, p. 6). Increasing citizens` participation can be considered as the means of providing electoral integrity (Norris, Frank, \& Coma, 2014). The problem of citizens' participation in the delimitation of electoral districts has not yet received a systematic study in the scientific literature. The first scientific publications on the subject of problems of citizens' participation in the process of district delimitation in certain US states appeared only in the 2010s. First of all, the articles of M. Altman and M. MacDonald (Altman \& McDonald, 2011; 2013) and empirical studies by B. Grofman and P. Miller (Miller \& Grofman, 2018), an article of T. Donovan on the prospects for applying the institutions of direct democracy in the process of electoral delimitation (Donovan, 2011). The purpose of this paper is to analyze the existing forms and prospects of citizens' participation in the delimitation of electoral districts.

The methodological basis of the study is the theory of citizens' participation, which offers a system of categories and ideas about the forms and patterns of citizens' participation in decision-making processes in governance. 


\section{METHODOLOGICAL FRAMEWORK}

Citizens' participation in modern theory is considered as a process that gives individuals the opportunity to influence decision-making in public administration and governance.

Within the framework of the methodological approach used here, public is usually understood as one or more individuals or legal entities, with the exception of state bodies and officials involved in the decision-making process due to their official duties (Karpov, 2012, p.14).

E. Cogan and S. Sharpe identify five advantages of citizens' participation in decision-making in public administration (Cogan \& Sharpe, 1986):

- Information and ideas on public issues;

- Public Support for planning decisions;

- Avoidance of protracted conflicts and costly delays;

- Reservoir of good will which can carry over to future decisions; and

- Spirit of cooperation and trust between the agency and the public.

In the Western theory of public administration, a steady interest for the problem of public participation was formed in the 1960s. In the seminal article by S. Arnstein in 1969, "Ladder of Citizen Participation" model was proposed, reflecting various stages of public influence on government decision-making (Arnstein, 1969, p. 220).

The "ladder" of citizens' participation provides for eight ascending stages of citizens' participation in decision-making which are grouped by S. Arnstein into three main forms (tab. 1).

\begin{tabular}{lcc}
\hline 8 & Citizen Control & Degrees of citizen power \\
7 & Delegated Power & \\
6 & Partnership & \\
5 & Placation & \\
4 & Consultation & \\
3 & Informing & Nonparticipation \\
2 & Therapy & \\
1 & Manipulation & \\
\hline
\end{tabular}

Table 1. The Ladder of Citizen Participation by S. Arnstein

The timeframes provided by law and practice, as an additional parameter established within the framework of the theory of citizens' participation, allows us to assess the possibilities of citizens' participation. 


\section{AUTHORITIES INVOLVED IN THE REDISTRICTING}

The subjects of decision-making in redistricting can be:

1) Parliament;

2) Election commissions;

3) Executive bodies;

4) Redistricting commissions.

The model in which the final scheme for electoral districts 'boundariesis approved by the parliament is the most common in the modern world (even if a special independent commission is responsible for preparing this project). According to this model, the parliament can usually accept or reject the whole project without making any partial changes (Handley, 2006, p. 83). However, at the same time, there are countries in which the project of electoral districts boundaries is drawn up by a special redistricting commission and it comes into force immediately after the approval of the commission without requiring parliamentary acceptance (New Zealand, Australia, India, etc.).

In a historical perspective, the number of countries where the charge for this task is transferred to independent election commissions or redistricting commissions is growing (Miller\& Grofman, 2013). Thus, a global trend is to protect the process of redistricting from the influence of political parties and politicians who are directly interested in the election results (Yoshinaka \& Murphy, 2010, p. 441). However, parliament in some countries still has the authority to determine the boundaries of constituencies. In particular, this situation exists in many US states (Chen \& Cottrell, 2016, p. 331), France (Sauger \& Grofman, 2016, p. 340), Italy.

Election commissions or other electoral management bodies are responsible for preparing a draft scheme of electoral districts in about $35 \%$ of the total number of modern countries in which delimitation is systematically carried out (Grishin, 2018a, p. 164). This model exists in Poland, Lithuania, Mexico, etc. In the Russian Federation, the Central Election Commission also prepares the electoral district map.

Executive bodies can usually perform the function of electoral redistricting in countries where there are no autonomous electoral commissions and the governmental model of electoral management exists (Handley \& Grofman, 2008, p. 92). In France, the Ministry of the Interior is responsible for the electoral delimitation. In Cameroon and Zimbabwe, the prepared project to change the boundaries of constituencies must be approved by the executive authority.

Special redistricting commissions are becoming more widespread in the modern world as temporary competent bodies entrusted with this func- 
tion (Grishin, 2018b, p. 102). In 2002, the Venice Commission of the Council of Europe adopted an important recommendation on the desirability of delimiting electoral districts with the participation of a special commission (Code ..., 2002).

In some countries, a court may also be involved in the process of developing a constituencies`scheme. This happens if the legislation provides for the possibility of judicial appeal against the boundaries of electoral districts (USA, UK, Ireland, etc.). The richest experience of such activity exists in the United States - over the years, American courts have made a large number of decisions to appeal against constituency boundaries (Rossiter et al, 2018, p. 617). Since this country belongs to the case-law system, some of these court decisions have normative significance and actually act as rules for the subsequent practice of electoral delimitation (especially on the inadmissibility of gerrymandering, differences in constituencies by the number of voters, etc.) (Magleby \& Mosesson, 2018, p.152).

In 1997, the Commonwealth of Nations countries adopted a Code of Recommended Rules for the Conduct of Elections, in accordance with which it was recommended in these countries to carry out the process of redistricting either by an election commission or by a special independent redistricting body (Morozova, 2015, p. 64).

The degree of centralization of redistricting process can be determined in different ways (Grishin \& Linders, 2020, p. 104). In most countries, this issue falls within the purview of the central government. In India, the central government determines not only the boundaries of constituencies for federal elections, but also several thousand constituencies for elections of deputies to regional representative bodies. As a result, the delimitation process is extremely laborious and takes several years.

In the United States, on the contrary, the delimitation process is completely decentralized: the federal parliament only distributes 435 seats of the House of Representatives between states, and after that each state independently and in different ways establishes the scheme of electoral districts. The United States is the only country in the world in which the electoral delimitation for the federal elections is fully within the competence of constituent entities, and not the federal center.

\section{REQUIREMENTS FOR THE REDISTRICTING}

In modern political science and practice, basic and generally accepted standards for electoral delimitation have been formulated (Grishin, 2019, p. 34 ), which should be met by democratic procedures for developing and deciding on the division of electoral districts: 
1) The frequency of revision of the boundaries of electoral districts;

2) Political impartiality;

3) Availability of clear rules for delimitation;

4) Participation of the highest authorities in the delimitation process;

5) Transparency and publicity;

6) Effective feedback from the public when discussing the draft scheme of electoral districts;

7) Reasonable cost of the delimitation process.

The process of electoral delimitation takes into account the following principles:

Equality of constituencies in number of voters. This principle is currently universally recognized and fundamental in the process of delimitation of electoral districts. Voters should have equal representation in parliament; therefore, ideally, each of the MPs should represent an equal number of voters.

Representativeness. Resilient communities must be represented in parliament. To achieve this, constituency boundaries should coincide with the boundaries of communities as far as possible. The implementation of this principle leads to the fact that constituencies can vary significantly in terms of social composition.

Respect for natural and administrative boundaries. Electoral districts should be determined taking into account administrative boundaries, geographic characteristics, and particular groups of the electorate. In most countries, it is legally established that when dividing electoral districts, it is necessary to take into account geographical conditions - both natural boundaries (large rivers, mountain ranges, etc.) and the boundaries of administrative-territorial entities.

Non-discrimination. The delimitation process must be free from manipulation to discriminate against voters based on race, color, language, religion, etc.

The compactness of the territory of the constituency. Many countries have established requirements for the form of the territory of an electoral district: the territory must be compact and continuous; its parts must be interconnected. Such a demand is directed against gerrymandering (Magleby $\&$ Mosesson, 2018, p. 103), against the manipulation of constituency boundaries in order to artificially create constituencies with a predominance of certain population groups.

Political impartiality. Constituency boundaries should not be established in the interests of certain political parties (candidates) at the expense of discriminating against others. Party "neutrality" presupposes the inadmissibility of gerrymandering. 


\section{TIMEFRAMES FOR CITIZENS' PARTICIPATION IN THE REDISTRICTING PROCESS}

One of the parameters that we have chosen to analyze citizens' participation in the delimitation of constituencies is the timeframes provided by law and practice. Modern countries use extremely different approaches to setting timeframes for public influence on decision-making in this area. The duration varies from a few days (in Russia) to 4-5 years (in India).

In the process of developing a scheme of electoral districts, there are three main stages:

1) Development and publication of the initial plan for the division of electoral districts;

2) Discussion (public hearings, holding meetings, receiving feedback and comments);

3) Preparation and presentation of the final project.

For the countries of Western democracies, it is typical that much more time is allocated for the public discussion of the draft, the presentation and consideration of comments than for the preparation of the first draft of the scheme of electoral districts.

The timeframes for citizens' participation in constituency delimitation is extremely limited in Russia. The public gets an opportunity to participate in the discussion of the electoral districts scheme only after the corresponding draft is submitted for consideration to the parliament. Formally, the CEC of the Russian Federation must submit a draft scheme of electoral districts no later than 80 days before the expiration of the deadline in which the elections are to be scheduled. Until this moment, the legislation does not provide for any procedures for public discussion of the project, holding public hearings, receiving comments and feedback from society or political parties. The legislation also does not provide that experts (geographers, statisticians, sociologists, etc.) should participate in the preparation of the project. After the draft has been submitted to the State Duma, it can be adopted in an extremely quick manner. For example, during the last delimitation in 2015, the Central Election Commission of the Russian Federation published the draft electoral district scheme on September 2, 2015. Already on September 15, it was submitted as a draft law to the State Duma, without any public discussion with the public and experts. The profile committee of the State Duma has set the deadline for receiving comments and comments until September 21. Already on September 25, 3 weeks after its publication, the law was adopted in the first reading. Thus, in 2015, the timeframes for citizens' participation in decision-making on the delimitation of single-member constituencies was only six calendar days. 
In Western countries, a fundamentally different approach is practiced, which consists in establishing a long period of public discussion of the draft delimitation of electoral districts. In the UK, during the last great delimitation of 2011-2013 the total duration of the commission's work was 2.5 years, of which six months were allotted for the preparation of the initial project, and more than one and a half years were spent on procedures providing for the possibility of citizens' participation (tab. 2).

In Ireland, during the 2016-2017 constituency delimitation, the project had a public comment period of three months.

In Canada, the schedule to the delimitation of electoral districts in 2012-2013 included an opportunity for citizens' participation during 10 months.

The extraordinary length of public debate on the draft constituency boundaries in India stems from the fact that the Federal Delimitation Commission is also responsible for determining the constituency boundaries for electing deputies at the state level. In this regard, the entire delimitation process is extremely laborious and requires lengthy approval procedures in each state.

\begin{tabular}{ll}
\hline & $\begin{array}{l}\text { Duration of the citizens' participation } \\
\text { period }\end{array}$ \\
\hline Russia & 6 days \\
Ireland & 3 months \\
Australia & 3 months \\
New Zealand & 3 months \\
Canada & 10 months \\
UK & 16 months \\
India & 5 years \\
\hline
\end{tabular}

Table 2. Timeframes for citizens' participation in the preparation and discussion of the draft electoral district scheme in some countries of the world

Reasonable timeframes are a key condition for citizens' participation in the constituency delimitation process. 


\section{FORMS OF CITIZENS' PARTICIPATION IN THE REDISTRICTING PROCESS}

Applying the typology of S. Arnstein, there is possibility to identify which of the forms of citizens' participation it proposed are practiced in the delimitation of electoral districts in modern countries of the world. Such a form of "real" citizens' participation as delegated power exists in Australia in the process of delimiting constituencies. The public is given a key mandate to make initial proposals. Public authorities should prepare the first draft only based on proposals received from citizens. In practice, this means that even responsible officials are forced to formulate their ideas as a proposal "from a private person", so that later the commission will have the right to work with this proposal and, if supported, include it in the document.

However, in most modern countries, the public does not receive "real powers" in the process of delimiting constituencies. Probably the most widespread form of citizens' participation in the delimitation of electoral districts in the modern world is consultations in the form of public hearings, and S. Arnstein classified this form in the category of tokinism. The consultations should also include public comments on the draft constituencies'scheme. The format of these "consultations" often guarantees the public many opportunities to influence the authorities and its effectiveness should not be underestimated. Because of studying the practice of public hearings in delimitation processes in the western US states in 2011-2012 P. Miller and B. Grofman concluded that $44 \%$ of proposals received from citizens were eventually implemented (Miller \& Grofman, 2018, p. 31).

In some cases, the practice of public consultation is characterized by a high level of institutionalization. As an example, there were five stages of electoral delimitation in New Zealand in 2013-2014:

1) Preparation and publication of the initial draft. The Representation Commission held its first meeting on October 16, 2013, and published an initial draft on November 21.

2) Reception of objections from citizens. Objections and comments from citizens were accepted within a month - until December 23, 2013, both in writing and online. The proposed project received 409 formal objections. They were systematized and published on January 14, 2014, for their public consideration and counter-objection.

3 ) Reception of counter-objections. They were accepted within two weeks - until January 29, 2014. During this period, 164 official counterobjections were received. 
4) Conducting public hearings on the project, objections and counterobjections. Public hearings were held from 10 to 19 February 2014.

5) Preparation and publication of the final document. After public discussion of the draft and consideration of comments, the Representation Commission prepared a final electoral district map within a few weeks, which was published on April 17, 2014.

In Australia, the delimitation process also includes consideration of both public comments and objections to comments received. In the work of delimitation commissions in Australia, five stages can be distinguished:

1) Receiving proposals from the public (30 days) and comments on the proposals received (14 days);

2) Preparation the first draft by the commission on the base of proposals and comments received;

3) Receiving comments on the first draft (28 days) and critical comments for comments (14 days);

4) Correction the first draft by the commission and public discussion (30 days);

5) Preparation the final scheme of electoral districts by the commission.

The key circumstance is a mandatory requirement for the authorities not only to accept citizens' proposals, but also to systematize them and give an official response. The existing format of work "forces" the commission to build its work around the proposals received from the public.

In the UK, during the 2011-2013 delimitation, public consultations were reflected in the schedule of commissions as follows:

1) The beginning of the redistricting - March 2011;

2) Consultation on the initial project (12 weeks) - from September 2011 to January 2012;

3) Public hearings - October, November 2011;

4) Consideration of the received proposals - spring 2012;

5) Consultation on the revised draft ( 8 weeks) - from November 2012 to January 2013;

6) Presentation of the final draft - summer 2013

It should be emphasized that the format of public discussion in wellestablished democracies goes beyond the notorious "consideration of opinion": citizens can independently formulate their proposals within the framework of the problem under consideration.

The research by P. Miller and B. Grofman confirmed that in the western US states, responsible authorities are more susceptible to certain types of recommendations and suggestions from the public, in particular, if they 
concern not large, but small territorial units (Miller \& Grofman, 2018, p . 32).

The "Placation" form proposed by S. Arnstein can be attributed to the practice, widespread at the present stage, of including members of the public in the delimitation commissions, primarily from among the experts. In 2002, the Venice Commission of the Council of Europe recommended the inclusion of a geographer, sociologist and, if necessary, representatives of national minorities in the delimitation commission (Code ..., 2002).

In some countries, the practice of citizens' participation in the delimitation of constituencies corresponds to such forms as therapy or manipulation, which are classified by S. Arnstein as nonparticipation. In Russia, the level of public attention to the electoral delimitation is so low that the authorities do not even need to imitate public discussion of these issues. Advocacy work to substantiate the "correctness" of the electoral district scheme chosen by the authorities is the only way to interact with the public.

\section{CONCLUSION}

The constituencies' delimitation belongs to those fields of governance in which the possibilities of citizens' participation and delegation of powers are objectively limited. Empowering the public with direct decision-making power in the constituency delimitation process seems unlikely: Australia's example remains rather an exception. However, modern practice has found ways to overcome these difficulties. The key factor that can increase the public impact on the authorities is the length of the timeframes for citizens' participation procedures. The long public consultation period makes it difficult for the authorities to make decisions without taking into account the proposals of citizens. In addition, it should be noted such a mechanism as the mandatory systematization and publication of proposals received from the public.

Applying the S. Arnstein's methodology to the study of citizens' participation in electoral delimitation reveals some of its shortcomings. First of all, the format of modern consultation provides the public with too much influence to be classified only as tokenism.

\section{References}

Altman, M., \& McDonald M. (2013). A Half-Century of Virginia Redistricting Battles: Shifting from Rural Malapportionment to Voting Rights to Public Participation. University of Richmond Law Review, 47(3), 771-831.

Altman, M., \& McDonald. M. (2011). Technology for Public Participation in Redistricting. In G. Moncrief (Ed.), Reapportionment and Redistricting in the West, (pp. 247-272), Lanham: Lexington Books. 
Arnstein, S. R. (1969). A Ladder of Citizen Participation. Journal of the American Planning Association, 35(4), 216-224. doi: 10.1080/01944366908977225

Best, R. E., Donahue, S. J., Krasno, J., Magleby, D. B., \& McDonald, M. D. (2018). Considering the Prospects for Establishing a Packing Gerrymandering Standard. Election Law Journal: Rules, Politics, and Policy, 17(1), 1-20. doi: 10.1089/elj.2016.0392

Chen, J., \& Cottrell, D. (2016). Evaluating partisan gains from Congressional gerrymandering: Using computer simulations to estimate the effect of gerrymandering in the US House. Electoral Studies, 44, 329-340. doi: 10.1016/j.electstud.2016.06.014

Code of Good Practice in Electoral Matters. (2002). Venice Commission.

Cogan, A., \& Sharpe, S. (1986). The theory of citizen involvement. In Planning analysis: The theory of citizen participation. University of Oregon. Retrieved from http://pages.uoregon.edu/rgp/PPPM613/class10theory.htm.

Donovan, T. (2011). Direct Democracy and Redistricting. In G. Moncrief (Ed.), Reapportionment and Redistricting in the West, (pp. 111-136). Lanham: Lexington Books.

Grishin, N., \& Leenders, A.M. (2020). Decentralization of Electoral Governance. Politeia, 3, 99-115. doi: 10.30570/2078-5089-2020-98-3-99-115 (In Russian).

Grishin, N. (2018). The History of Origin of Electoral Commissions. Politeia, 89(2), 156-169. doi: 10.30570/2078-5089-2018-89-2-156-169 (In Russian).

Grishin, N. (2018). The Phenomenon of Constituency Boundaries Commissions: Development and Prospects. Polis. Political. Studies, (4), 100-114. doi: 10.17976/jpps/2018.04.08 (In Russian).

Grishin, N. (2019). Development of International Electoral Standards: What's Next? Political Science, (1), 33-47. doi: 10.31249/poln/2019.01.02 (In Russian).

Handley L., \& Grofman B. (Eds.). (2008). Redistricting in comparative perspective. New York: Oxford University Press.

Handley, L. (2006). Delimitation Equity Project Resource Guide. IFES

Hunt, C. R. (2018). When does redistricting matter? Changing conditions and their effects on voter turnout. Electoral Studies, 54, 128-138. doi: 10.1016/j.electstud.2018.05.007

Karpov, A.S. (2012). Forms of public participation in decision-making. Moscow: RANEPA (In Russian)

Magleby, D. B., \& Mosesson, D. B. (2018). A New Approach for Developing Neutral Redistricting Plans. Political Analysis, 26(02), 147-167. doi: 10.1017/pan.2017.37

Martínez i Coma, F., \& Lago, I. (2016). Gerrymandering in comparative perspective. Party Politics, 24(2), 99-104. doi: 10.1177/1354068816642806 
Miller, P., \& Grofman, B. (2013).Redistricting Commissions in the Western United States. UC Irvine Law Review, 3(3), 637-668.

Miller, P., \& Grofman, B. (2018). Public Hearings and Congressional Redistricting: Evidence from the Western United States 2011-2012. Election Law Journal: Rules, Politics, and Policy, 17(1), 21-38. doi: 10.1089/elj.2016.0425

Morozova, O. S. (2013). Formation of constituencies as a method of electoral targeting. Caspian Region: Politics, Economics, Culture, (1), 106-112. (In Russian)

Morozova, O. S. (2015). Electoral Systems Design: The Possibilities of Electoral Engineering. Ryazan: RSU (In Russian)

Nagle, J. F. (2019). What Criteria Should Be Used for Redistricting Reform? Election Law Journal: Rules, Politics, and Policy, 18(1), 1-15. doi: 10.1089/elj.2018.0514

Norris, P., Frank, R. W., \& Coma, F. M. i (Eds.). (2014). Advancing Electoral Integrity. Oxford: Oxford University Press.

Rossiter, K. M., Wong, D. W. S., \& Delamater, P. L. (2018). Congressional Redistricting: Keeping Communities Together? The Professional Geographer, 70(4), 609-623. doi: 10.1080/00330124.2018.1443477

Sauger, N., \& Grofman, B. (2016). Partisan bias and redistricting in France. Electoral Studies, 44, 388-396. doi: 10.1016/j.electstud.2016.09.007

Winburn, J., \& Wagner, M. (2010). Carving Voters Out: Redistricting's Influence on Political Information, Turnout, and Voting Behavior. Political Research Quarterly, 63(2), 373-386. doi: 10.1177/1065912908330728

Yoshinaka, A., \& Murphy, C. (2010). The Paradox of Redistricting: How Partisan Mapmakers Foster Competition but Disrupt Representation. Political Research Quarterly, 64(2), 435-447. doi: 10.1177/1065912909355716

\section{Список литературы}

Altman, M., \& McDonald M. (2013). A Half-Century of Virginia Redistricting Battles: Shifting from Rural Malapportionment to Voting Rights to Public Participation. University of Richmond Law Review, 47(3), 771-831.

Altman, M. \& McDonald. M. (2011). Technology for Public Participation in Redistricting. In G. Moncrief (Ed.), Reapportionment and Redistricting in the West, (pp. 247-272), Lanham: Lexington Books.

Arnstein, S.R. (1969). A Ladder of Citizen Participation. Journal of the American Planning Association, 35(4), 216-224. doi: 10.1080/01944366908977225

Best, R. E., Donahue, S. J., Krasno, J., Magleby, D. B., \& McDonald, M. D. (2018). Considering the Prospects for Establishing a Packing Gerrymandering Standard. Election Law Journal: Rules, Politics, and Policy, 17(1), 1-20. doi: 10.1089/elj.2016.0392

Chen, J., \& Cottrell, D. (2016). Evaluating partisan gains from Congressional gerrymandering: Using computer simulations to estimate the effect of gerrymandering 
in the US House. Electoral Studies, 44, 329-340. doi: 10.1016/j.electstud.2016.06.014.

Code of Good Practice in Electoral Matters. (2002). Venice Commission.

Cogan, A., \& Sharpe, S. (1986). The theory of citizen involvement. In Planning analysis: The theory of citizen participation. University of Oregon. Retrieved from http://pages.uoregon.edu/rgp/PPPM613/class10theory.htm.

Donovan, T. (2011). Direct Democracy and Redistricting.In G. Moncrief (Ed.), Reapportionment and Redistricting in the West, (pp. 111-136). Lanham: Lexington Books.

Handley L., \& Grofman B. (Eds.). (2008). Redistricting in comparative perspective. New York: Oxford University Press.

Handley, L. (2006). Delimitation Equity Project Resource Guide. IFES

Hunt, C. R. (2018). When does redistricting matter? Changing conditions and their effects on voter turnout. Electoral Studies, 54, 128-138. doi: 10.1016/j.electstud.2018.05.007

Magleby, D. B., \& Mosesson, D. B. (2018). A New Approach for Developing Neutral Redistricting Plans. Political Analysis, 26(02), 147-167. doi: 10.1017/pan.2017.37

Martínez i Coma, F., \& Lago, I. (2016). Gerrymandering in comparative perspective. Party Politics, 24(2), 99-104. doi: 10.1177/1354068816642806

Miller, P., \& Grofman, B. (2013). Redistricting Commissions in the Western United States. UC Irvine Law Review, 3(3), 637-668.

Miller, P., \& Grofman, B. (2018). Public Hearings and Congressional Redistricting: Evidence from the Western United States 2011-2012. Election Law Journal: Rules, Politics, and Policy, 17(1), 21-38. doi: 10.1089/elj.2016.0425

Rossiter, K. M., Wong, D. W. S., \& Delamater, P. L. (2018). Congressional Redistricting: Keeping Communities Together? The Professional Geographer, 70(4), 609-623. doi: 10.1080/00330124.2018.1443477

Sauger, N., \& Grofman, B. (2016). Partisan bias and redistricting in France. Electoral Studies, 44, 388-396. doi: 10.1016/j.electstud.2016.09.007

Winburn, J., \& Wagner, M. (2010). Carving Voters Out: Redistricting's Influence on Political Information, Turnout, and Voting Behavior. Political Research Quarterly, 63(2), 373-386. doi: 10.1177/1065912908330728

Yoshinaka, A., \& Murphy, C. (2010). The Paradox of Redistricting: How Partisan Mapmakers Foster Competition but Disrupt Representation. Political Research Quarterly, 64(2), 435-447. doi: 10.1177/1065912909355716

Гришин, Н. В. \& Линдерс, А. М. (2020). Децентрализация системы управления выборами. Полития, 98(3), 99-115.doi: 10.30570/2078-5089-2020-98-3-99115 
Гришин, Н. В. (2018). История возникновения избирательных комиссий. Полития, 89(2), 156-169. doi: 10.30570/2078-5089-2018-89-2-156-169.

Гришин, Н. В. (2018). Комиссии по делимитации избирательных округов: становление и перспективы политического института. Полис. Политические исследования, (4), 100-114. doi.org/10.17976/jpps/2018.04.08

Гришин, Н. В. (2019). Развитие международных избирательных стандартов: что дальше? Политическая наука, 1, 33-47. doi: 10.31249/poln/ 2019.01.02

Карпов, А. С. (2012). Формы общественного участия в принятии решений. Москва: РАНХиГС.

Морозова, О. С. (2013). Формирование избирательных округов как метод электорального таргетирования. Каспийский регион: политика, экономика, культура, (1), 106-112.

Морозова, О. С. (2015). Проектирование избирательных систем: возможности избирательной инженерии. Рязань: РГУ. 